OSAHS

\title{
Orthopaedic treatment effects of functional therapy on the sagittal pharyngeal dimensions in subjects with sleep-disordered breathing and Class II malocclusion
}

\author{
Effetti del trattamento ortopedico-funzionale sulle dimensioni sagittali faringee \\ in soggetti con disturbi respiratori del sonno e malocclusione di Classe II \\ C. PAVONI ${ }^{1}$, E. CRETELLA LOMBARDO ${ }^{1}$, R. LIONE¹ ${ }^{1}$, P. BOLLERO², F. OTTAVIANI ${ }^{1}$, P. COZZA ${ }^{1,3}$ \\ ${ }^{1}$ Department of Clinical Sciences and Translational Medicine, University of Rome Tor Vergata, Italy; ${ }^{2}$ Department of \\ Systems Medicine, University of Rome Tor Vergata, Italy; ${ }^{3}$ Department of Orthodontics, University Zoja e Këshillit të \\ Mirë, Tirane, Albania
}

\section{SUMMARY}

The purpose of this cephalometric study was to evaluate the craniofacial changes induced by functional treatment of mandibular advancement with special regard to pharyngeal sagittal airway dimensions, tongue and hyoid bone position in subjects with sleep-disordered breathing (SDB) and dentoskeletal Class II malocclusions compared with an untreated Class II control group. 51 subjects (24 female, 27 male; mean age $9.9 \pm 1.3$ years) with Class II malocclusion and SDB consecutively treated with a functional appliance (Modify Monobloc, MM) were compared with a control group of 31 subjects ( 15 males, 16 females; mean age $10.1 \pm 1.1$ ) with untreated Class II malocclusion. For the study group, mode of breathing was defined by an otorhinolaryngologist according to complete physical examination. The parents of all participants completed a modified version of the paediatric sleep questionnaire, PSQ-SRBD Scale, by Ronald Chervin (the Italian version in 22 items form) before and after the trial. Lateral cephalograms were available at the start and end of treatment with the MM. Descriptive statistics were used for all cephalometric measurements in the two groups for active treatment changes. Significant, favourable skeletal changes in the mandible were observed in the treated group after T2. Significant short-term changes in sagittal airway dimensions, hyoid position and tongue position were induced by functional therapy of mandibular advancement in subjects with Class II malocclusion and SDB compared with untreated controls. After orthodontic treatment, a significant reduction in diurnal symptoms was observed in 45 of the 51 participants who had received an oral appliance. Orthodontic treatment is considered to be a potential therapeutic approach for SDB in children. Orthodontists are playing an increasingly important role in managing snoring and respiratory problems by oral mandibular advancement devices and rapid maxillary expansion.

KEY WORDS: Sleep-disordered breathing • Mandibular advancement device • Functional treatment

\section{RIASSUNTO}

Con il termine Sleep disorder breathing (SDB) s'intendono tutte quelle difficoltà respiratorie che si verificano durante il sonno. Si può osservare una grande variabilità nella sintomatologia dei pazienti affetti da $S D B$, direttamente proporzionale alla resistenza che le vie aeree superiori offrono al passaggio dell'aria quando queste sono ostruite. L'SDB rappresenta un ampio ventaglio di disturbi che vanno dal russamento primario fino ad arrivare alle apnee ostruttive del sonno. I bambini con problemi respiratori tendono a compensare l'ostruzione delle vie aeree assumendo posizioni caratteristiche, tali da garantire il mantenimento della pervietà delle vie aeree durante il sonno. Un'anomalia di posizione nel sonno, durante la fase di crescita e sviluppo, si ripercuote in un'alterazione dello sviluppo occlusale e in una modifica del pattern di crescita. Le principali alterazioni sono a carico del mascellare superiore, dell'altezza facciale, del tono muscolare e della posizione mandibolare; nei bambini con SDB, infatti, è spesso presente un pattern scheletrico di Classe II, con lunghezza mandibolare ridotta ed overbite aumentato. Lo scopo del presente studio è stato quello di valutare i cambiamenti craniofacciali indotti dalla terapia funzionale di avanzamento mandibolare con particolare riferimento alla dimensione sagittale delle vie aeree, superiori ed inferiori, alla posizione dell'osso ioide e alla posizione della lingua in soggetti con SDB e malocclusione di Classe II, messi a confronto con un gruppo controllo in Classe II non trattato. 51 soggetti (24 femmine, 27 maschi; età media 9,9 1,3 anni) con malocclusione dentoscheletrica di Classe II e SDB trattati con il dispositivo funzionale Monoblocco Modificato (MM) sono stati messi a confronto con un gruppo controllo non trattato di 31 soggetti (15 maschi, 16 femmine; età media 10,1 \pm 1,1 anni) presentanti la stessa malocclusione senza SDB. Il gruppo di studio è stato valutato da uno specialista in otorinolaringoiatria per la definizione del tipo di respirazione ed è stato sottoposto ad un esame fisico completo. I genitori di tutti i pazienti hanno completato un questionario per valutare la presenza di sintomi notturni e diurni prima e dopo il test clinico (versione italiana in 22 punti del Pediatric sleep questionnaire, ideato da Ronald Chervin). Le teleradiografie in proiezione latero laterale sono state analizzate all'inizio e alla fine del trattamento con MM. Tutte le misurazioni cefalometriche dei due gruppi sono state analizzate attraverso dei test per la valutazione statistica dei cambiamenti avvenuti durante il trattamento. I risultati hanno evidenziato dei cambiamenti scheletrici favorevoli nel gruppo trattato a tempo T2. La terapia funzionale di avanzamento mandibolare ha indotto dei cambiamenti statisticamente significativi nella dimensione sagittale delle vie aeree, nella posizione dell'osso ioide e nella posizione della lingua in soggetti di Classe II affetti da SDB rispetto ai controlli non trattati. Dopo la terapia ortodontica in 45 pazienti del gruppo di studio è stata osservata una riduzione dei sintomi diurni di SDB. Il trattamento 
con apparecchiature funzionali, non solo migliora i rapporti tra mascellare superiore e mandibola, ma riduce anche il rischio del collasso delle vie aere superiori. La logica terapeutica si basa sul concetto che tutte le anomalie, legate ad un retroposizionamento mandibolare, beneficiano della terapia funzionale di avanzamento mandibolare, che è in grado di ampliare lo spazio posteriormente alla lingua ed allo stesso tempo promuovere l'avanzamento linguale. Lo spostamento anteriore della mandibola influenza la posizione dell'osso ioide e la posizione della lingua, aumentando lo spazio intermascellare in cui quest'ultima alloggia e migliorando la morfologia delle vie aeree superiori. Ne consegue sia la risoluzione della malocclusione scheletrica di Classe II che il miglioramento dei rapporti retrofaringei, eliminando quei fattori predisponenti per lo sviluppo di disturbi respiratori in età adulta.

PAROLE CHIAVE: Problematiche respiratorie nel sonno $\bullet$ Dispositivo di avanzamento mandibolare $\bullet$ Terapia funzionale

Acta Otorhinolaryngol Ital 2017;37:479-485

\section{Introduction}

Sleep-disordered breathing (SDB) is a general term for breathing difficulties occurring during sleep. SDB may be defined as a disorder characterised by prolonged increased upper airway resistance, partial upper airway obstruction, or complete obstruction that disrupts pulmonary ventilation, oxygenation, or sleep quality ${ }^{1}$.

There is a large variability in the symptoms of SDB directly related to increasing upper airway resistance. It represents a "continuum" of respiratory disorders from primary snoring to obstructive sleep apnoea (OSA) ${ }^{2}$.

Some children compensate the airway obstruction by sleeping in a knee-chest position and with their neck hyper-extended to give the best chance of maintaining their airway while asleep ${ }^{3}$. This form of breathing may change the growth pattern of the face and lead to morphological and functional alterations in the organism ${ }^{4}$.

Mouth breather children develop abnormalities, such as speech disorders, facial deformities, abnormal body posture and inadequate positioning of the teeth ${ }^{56}$.

Several studies examined anatomic differences between SDB subjects and nasal breathers using traditional cephalometric tracing, model analysis and three-dimensional (3D) radiography ${ }^{7-13}$.

Model analysis revealed that SDB patients had narrower maxilla and mandible compared with the control group; the tongue may compensate for the reduced inter-arch dimensions and such as assume a more upward and backward position ${ }^{14}$.

Cozza et al. in $2004^{12}$ observed that the children with respiratory symptoms demonstrated a skeletal Class II pattern with a reduced mandibular length, deep overbite and the hyoid bone was located superiorly. Guilleminault et al. ${ }^{15}$ suggested that children with retroposition of the mandible, steep mandibular plane, high hard palate, long oval-shaped face, or long soft palate were highly likely to have sleep-disordered breathing.

Kim et al. ${ }^{16}$ in 2010 showed that the mean total airway volume, extending from the anterior nasal cavity and the nasopharynx to the epiglottis, in retrognathic patients was significantly smaller than that of patients with a normal anteroposterior skeletal relationship.
The most common cause of SDB is adenotonsillar hypertrophy. Children with adenotonsillar hypertrophy are usually treated by adenotonsillectomy (ATE). Children who do not improve after adenotonsillectomy tend to have a narrower epipharyngeal air space, a more poorly developed maxilla and mandibular retrusion ${ }^{17}$.

Oral appliances and functional orthopaedic appliances have been used in children to shift the mandible forwards, enlarge the upper airway and improve respiratory function in patients who have OSAS and craniofacial anomalies ${ }^{17} 18$. Mandibular advancement devices, in adult patients with mild or moderate obstructive sleep apnoea, are successful in improving AHI, and comparison with inactive appliances suggests that mandibular advancement is crucial in establishing efficacy ${ }^{19} 20$; whereas only a few studies in the literature have evaluated mandibular advancement for treatment of respiratory difficulties in growing patients ${ }^{2}$. The aim of the present study was to evaluate the craniofacial changes induced by functional treatment of mandibular advancement with special regard to the pharyngeal sagittal airway dimensions, tongue and hyoid bone position in subjects with sleep-disordered breathing and dentoskeletal Class II malocclusions compared with an untreated Class II control group immediately after therapy.

\section{Materials and methods}

The study project was approved by the Ethical Committee at the Tor Vergata Hospital in Rome, and informed consent was obtained from the subjects' parents.

A sample of 90 Class II subjects was selected among patients of the Department of Orthodontics at the University of Rome Tor Vergata.

51 consecutive subjects ( 24 female and 27 male, mean age $9.9 \pm 1.3$ years), who were seen for sleep-disordered breathing, were selected for the study group and were treated for a mean period of 1.8 years $(\mathrm{SD}=1.1)$ (Table I); 31 Class II subjects without SDB (15 males and 16 females, mean age $10.1 \pm 1.1$ ) were selected for comparison and were observed for a mean period of 1.9 years $(\mathrm{SD}=0.8)$ (Table I). The remaining 8 subjects were excluded for the presence of systemic disorders. Demographic data of the treated and control samples are reported in Table I. 
Table I. Demographics for treatment and control group.

\begin{tabular}{lcccccc} 
& \multicolumn{2}{c}{ Age at T1, y } & \multicolumn{2}{c}{ Age at T2, y } & \multicolumn{2}{c}{ T1-T2 interval, y } \\
& Mean & SD & Mean & SD & Mean & SD \\
Treated group & 9.9 & 1.3 & 11.7 & 1.9 & 1.8 & 1.1 \\
Control group & 10.1 & 1.1 & 12.0 & 0.3 & 1.9 & 0.8 \\
\hline
\end{tabular}

At T1, all patients had a Class II malocclusion characterised by ANB of $4^{\circ}$ or more, overjet greater than $5 \mathrm{~mm}$, full Class II or end-to-end molar relationships, deep overbite, normo-hypo divergence, no adenoidectomy or tonsillectomy, absence of previous orthodontic treatment and the absence of craniofacial syndromes.

All patients were in category 2 or 3 of the cervical vertebrae maturation indices, which indicates that they have not reached the peak pubertal growth spurt ${ }^{21}$.

For the study group, mode of breathing was defined by an otorhinolaryngologist according to complete physical examination. The parents of all participants completed a modified version of the paediatric sleep questionnaire, PSQ-SRBD Scale, by Ronald Chervin ${ }^{22}$ (the Italian version in 22 items form) before and after the trial. The questions sought information about child's daytime symptoms (including sleepiness, irritability, tiredness, school problems, morning headache, oral breathing, and nasal stuffiness) and night-time symptoms (including habitual snoring, apnoea, restless sleep, and nightmares).

The treatment protocols consisted of a modified monoblock (MM) made by a construction bite that positioned the mandible anteriorly in an edge to edge incisor relationship. It was fabricated from acrylic resin which is physiologically harmless, insoluble in water, odour free and inactive. The central screw was activated only once a month to follow maxillary transversal growth. Appliances were checked at regular recall.

The subjects were instructed to wear their appliances fulltime. During treatment, the absence of acrylic on the occlusal surface of posterior mandibular teeth encouraged them to erupt. The MM appliance also incorporated a Tucat's pearl on a sliding wire to determine the reference point for the tip of the tongue. Tucat's pearl allows the placement of the tongue tip against the palatal aspect of the alveolar process, behind the maxillary incisors, to improve muscle function and the habitual position of the tongue ${ }^{10}$. Treatment with the MM appliance ended with the achievement of Class I molar relationship. After this period, subjects used the appliance at night only. To be included in the study, all the subjects had to present with lateral cephalograms available at two time periods: T1, at the start of treatment/observation period and $\mathrm{T} 2$, at the end of therapy/observation period.

The success of therapy in correcting the Class II malocclusion in each patient at the end of the observation period was not a determining factor for patient recruitment, an approach that lowered any potential selection bias.
The control group was observed in the same period because therapy with functional appliances was postponed to pubertal growth spurt.

\section{Cephalometric analysis}

All lateral cephalograms of each patient were hand traced at a single sitting by one investigator (ECL). Landmark location and the accuracy of the anatomical outlines were verified by a second (CP). A customized digitisation regimen (Viewbox, version 4.0, dHAL Software, Kifissia, Greece) was created and used for cephalometric evaluation.

Lateral cephalograms for each patient at $\mathrm{T} 1$ and $\mathrm{T} 2$ were digitised, and a custom cephalometric analysis was used.

The cephalometric measurements used were (Fig. 1):

1. Dento-skeletal measurements: $\mathrm{SNA}^{\circ}, \mathrm{SNB}^{\circ}, \mathrm{ANB}^{\circ}$, $\mathrm{Co}-\mathrm{Me}(\mathrm{mm}), \mathrm{SN}^{\wedge} \mathrm{Go}-\mathrm{Gn}^{\circ}, \mathrm{FMA}^{\circ}, \mathrm{OVJ}^{\circ}, \mathrm{OVB}^{\circ}$.

2. Airway dimension: PNS-AD1 (mm): lower airway thickness; distance between the PNS and AD1; AD1$\mathrm{Ba}(\mathrm{mm})$ : lower adenoid thickness; PNS-AD2: upper airway thickness; AD2-H: upper adenoid thickness; Upper pharynx dimension: the minimum distance between Phw1 and Psp; Lower pharynx dimension: the minimum distance between Phw2 and Tb.

3. Hyoid bone: AH-C3 horizontal ( $\mathrm{mm})$ : the horizontal distance from $\mathrm{AH}$ to $\mathrm{C} 3$; $\mathrm{AH}-\mathrm{C} 3$ vertical $(\mathrm{mm})$ : the vertical distance from $\mathrm{AH}$ to $\mathrm{C} 3$; $\mathrm{AH}-\mathrm{FH}(\mathrm{mm})$ : the distance from AH to Frankfort horizontal; AH-Rgn (mm): the horizontal position of the hyoid; AH-AH1 (mm): the vertical position of the hyoid on the mandibular plane; AH-SN (mm): the vertical position of the hyoid to the SN line.

4. Tongue: V-T $(\mathrm{mm})$ : the distance from the intersection of the epiglottis and the base of the tongue to the tip of the tongue; $\mathrm{H}$ perpendicular to $\mathrm{V}-\mathrm{T}$ : representing tongue height; $\mathrm{V}-\mathrm{T}^{\wedge} \mathrm{FH}^{\circ}$ : representing the vertical position of the tongue.

5. Soft palate and oropharyngeal dimensions: MPW $(\mathrm{mm})$ : middle pharyngeal width measured from the intersection of a perpendicular line from $U$ to the posterior pharyngeal wall; U-PNS (mm): representing the length of the soft palate.

\section{Method error}

To analyse the error of the method, 20 randomly selected lateral cephalograms were re-digitised and re-measured within a week by the same operator.

\section{Statistical analysis}

Data analysis was performed by using the Statistical Package for Social Sciences version 22.0 software (SPSS Inc., Chicago, III). The Mann-Whitney U-test was applied to comparisons between craniofacial starting forms in the treated group vs control group. Descriptive statistics were used for all the cephalometric measurements in the two groups for the T2T1 changes (active treatment changes). Shapiro Wilks' test 
revealed a normal distribution for the data. The two sample t-test was applied to compare T1-T2 changes in the treated sample vs the control group $(\mathrm{p}<0.05)$. The males and females in each group were matched at T1 in terms of skeletal relationships and skeletal maturation and a student's T-test was applied at T2 to evaluate differences in skeletal relationships between the two subgroups.

\section{Results}

There were no significant differences between the treated group and the control group at study start (Table II).

Descriptive statistics and comparisons of the T2-T1 changes between treated and untreated control groups are given in Table III.

No significant differences between male and female subgroups were found at $\mathrm{T} 2$ for skeletal relationship.

Initial problems with use of MM include excessive salivation and discomfort at awakening after having a repositioning device in the mouth all night. These adverse effects were found to gradually diminish within a few days after beginning of treatment, and following this period all children and their parents reported good compliance with the MM. The appliances were, therefore, well tolerated. No dysfunctions of the dentition were noted.

The hyoid was located more anteriorly in treated patients: the value of AH-C3 horizontal presented a significant increase of $+3.6 \mathrm{~mm}$ in the T1-T2 period. In addition, the hyoid was found in a lower position at the end of treatment as determined from the increase of distance AH-SN and $\mathrm{AH}-\mathrm{FH}$ (+ $7.2 \mathrm{~mm}$ and $+6.4 \mathrm{~mm}$ respectively).

The treated group exhibited a significant increase of the length of the soft palate (U-PNS: $+1.6 \mathrm{~mm}$ ) and an increase of superior posterior and inferior airway space (Phw1-Psp: + $4.5 \mathrm{~mm}$ and Phw2-Tb: $+4.3 \mathrm{~mm}$ ).

Middle pharyngeal width and upper airway thickness were significantly increased (MPW: + $2.1 \mathrm{~mm}$; PNS-AD1: + 1.2 $\mathrm{mm})$ and a reduction of upper and lower adenoid thickness (AD2-H, - $1.0 \mathrm{~mm}$ e AD1-Ba, - $0.4 \mathrm{~mm}$ ) was observed.

The comparisons between the two groups showed that treated patients presented a more anterior position of the tongue $(\mathrm{V}-\mathrm{T},+5.7 \mathrm{~mm})$ and a reduction of its height (H perp VT, - 4,5 mm). Moreover, treated subjects presented a more lower position of the tongue as determined from the value of $\mathrm{VT}^{\wedge} \mathrm{FH}\left(-2.2^{\circ}\right)$.

When compared with controls, the treated group present-
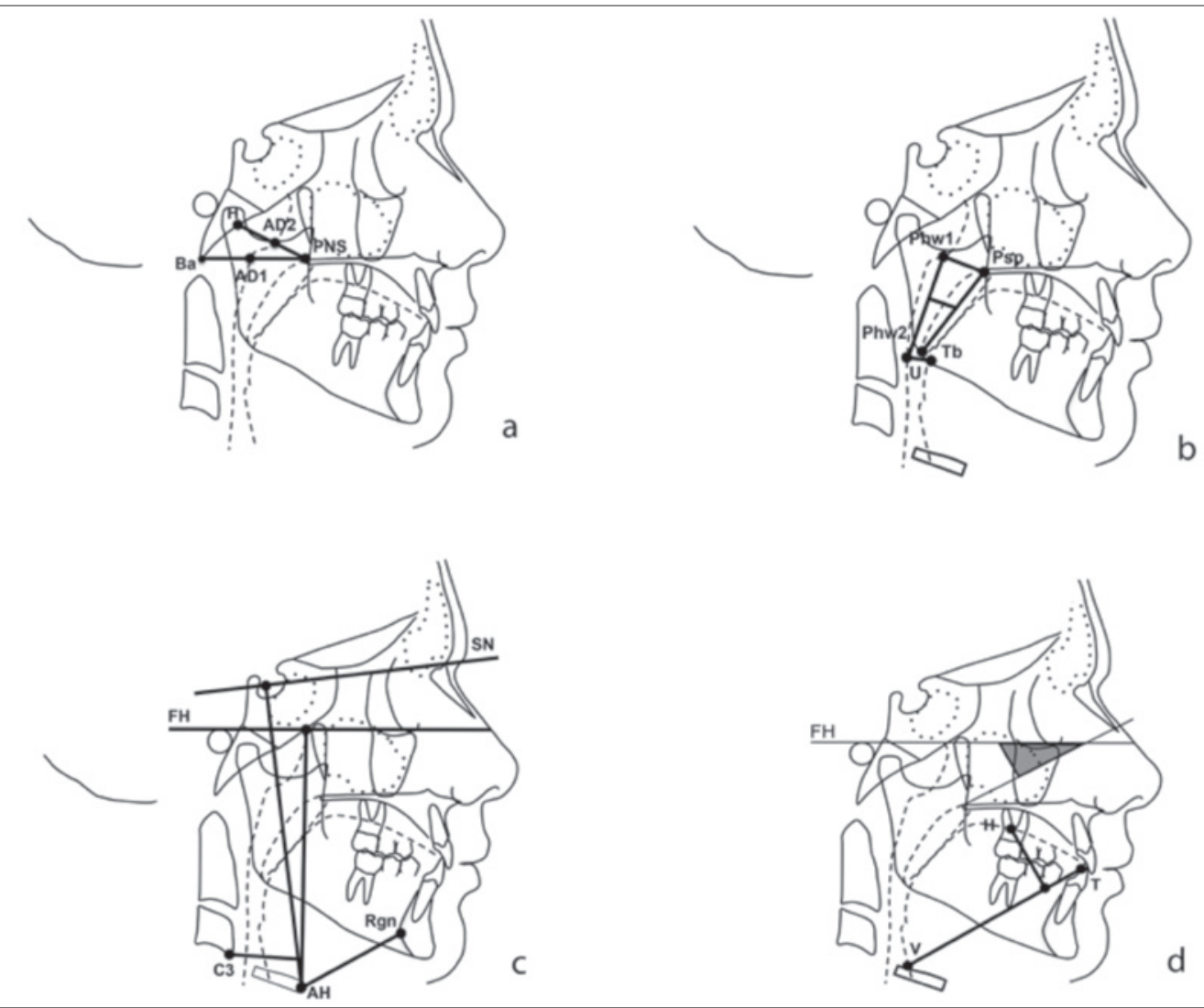

Fig. 1. a) Cephalometric analysis: Airway dimension [PNS-AD1(mm); AD1-Ba (mm); PNS-AD2 (mm); AD2-H (mm)]; b) Soft palate and oropharyngeal dimensions [MPW (mm); U-PNS; Phw1-Psp (mm); Phw2-Tb (mm)]; c) Hyoid bone [AH-C3 horizontal (mm), the horizontal distance from AH to C3; AH-C3 vertical $(\mathrm{mm})$, the vertical distance from $\mathrm{AH}$ to $\mathrm{C} 3 ; \mathrm{AH}-\mathrm{FH}(\mathrm{mm})$, the distance from AH perpendicular to Frankfort horizontal; AH-RGn (mm), the horizontal distance from $\mathrm{AH}$ to $\mathrm{RGn} ; \mathrm{AH}-\mathrm{AH} 1(\mathrm{~mm})$, the vertical distance from $\mathrm{AH}$ to the mandibular plane (AH1); $\mathrm{AH}-\mathrm{SN}(\mathrm{mm})$, the vertical position from AH perpendicular to SN line]; d) Tongue [VT (mm); H perp VT (mm); VT^FH (degrees)]. 
Table II. Starting forms for the treated vs control group.

\begin{tabular}{|c|c|c|c|c|c|}
\hline \multirow[b]{2}{*}{$\begin{array}{l}\text { Dentoskeletal } \\
\text { measurements }\end{array}$} & \multicolumn{2}{|c|}{$\begin{array}{l}\text { Treated } \\
\text { group }\end{array}$} & \multicolumn{2}{|c|}{$\begin{array}{c}\text { Control } \\
\text { group }\end{array}$} & \multirow[t]{2}{*}{$\begin{array}{c}\text { Mann-Whitne } \\
\text { U test }\end{array}$} \\
\hline & Mean & SD & Mean & SD & \\
\hline \multicolumn{6}{|l|}{ Sagittal analysis } \\
\hline SNA $\left(^{\circ}\right)$ & 82.5 & 3.0 & 81.5 & 2.6 & ns \\
\hline $\operatorname{SNB}\left({ }^{\circ}\right)$ & 75.7 & 2.8 & 74.8 & 2.1 & ns \\
\hline $\operatorname{ANB}\left({ }^{\circ}\right)$ & 6.8 & 1.8 & 6.7 & 1.0 & ns \\
\hline Co-Me (mm) & 106.8 & 4.8 & 105.61 & 4.5 & ns \\
\hline \multicolumn{6}{|l|}{ Vertical analysis } \\
\hline $\mathrm{FMA}\left({ }^{\circ}\right)$ & 23.3 & 4.0 & 21.6 & 1.5 & ns \\
\hline $\mathrm{SN} \wedge \mathrm{GoGn}$ & 34.2 & 4.7 & 33.1 & 2.6 & ns \\
\hline CoGoMe $\left(^{\circ}\right)$ & 124.8 & 6.3 & 122.1 & 5.0 & ns \\
\hline \multicolumn{6}{|l|}{ Dental analysis } \\
\hline Overjet (mm) & 7.0 & 3.9 & 6.1 & 1.8 & ns \\
\hline Overbite (mm) & 5.5 & 2.3 & 5.6 & 1.2 & ns \\
\hline \multicolumn{6}{|l|}{ Hyoid } \\
\hline AH-C3 hor (mm) & 24.3 & 2.7 & 25.3 & 3.3 & ns \\
\hline $\mathrm{AH}-\mathrm{C} 3$ vert $(\mathrm{mm})$ & 2.9 & 4.6 & 2.2 & 4.8 & ns \\
\hline $\mathrm{AH}-\mathrm{FH}(\mathrm{mm})$ & 64.0 & 5.2 & 66.0 & 5.4 & ns \\
\hline AH-RGn (mm) & 33.2 & 4.1 & 34.7 & 5.9 & ns \\
\hline $\mathrm{AH}-\mathrm{AH} 1$ (mm) & 10.7 & 5.6 & 12.2 & 3.2 & ns \\
\hline AH-SN (mm) & 78.2 & 5.4 & 80 & 5.8 & ns \\
\hline \multicolumn{6}{|c|}{ Soft palate and pharynx } \\
\hline U-PNS (mm) & 24.8 & 3.5 & 26.3 & 3.4 & ns \\
\hline Phw1-Psp (mm) & 8.7 & 3.9 & 10.1 & 3.4 & ns \\
\hline Phw2-Tb (mm) & 10.4 & 3.5 & 11.1 & 2.8 & ns \\
\hline MPW (mm) & 5.4 & 2.3 & 6.4 & 2.5 & ns \\
\hline PNS-AD1 (mm) & 16.1 & 4.4 & 18.0 & 5.5 & ns \\
\hline PNS-AD2 (mm) & 12.1 & 5.9 & 13.2 & 4.1 & ns \\
\hline AD1-Ba (mm) & 20.9 & 4.7 & 20.9 & 5.2 & ns \\
\hline AD2-H (mm) & 13.2 & 4.4 & 14.1 & 3.4 & ns \\
\hline \multicolumn{6}{|l|}{ Tongue } \\
\hline VT (mm) & 60.8 & 2.5 & 59.5 & 4.1 & ns \\
\hline H perp VT (mm) & 12.3 & 3.5 & 12.3 & 2.7 & ns \\
\hline $\mathrm{VT} \wedge \mathrm{FH}\left({ }^{\circ}\right)$ & 18.4 & 1.2 & 17.4 & 3.6 & ns \\
\hline
\end{tabular}

ed a significant decrease of $-1.7^{\circ}$ in $\mathrm{ANB}^{\circ}$, while mandibular length was significantly increased by $+4.0 \mathrm{~mm}$ (Co-Me). No significant differences were found between the two groups in vertical analysis.

Both overjet and overbite exhibited a significant improvement in treated subjects $(-2.8 \mathrm{~mm}$ and $-1.3 \mathrm{~mm}$ respectively) compared to the control group.

After the trial, the children's parents again completed the same questionnaire and children underwent a new physical examination. After 1 year and 8 months of orthodontic treatment, a significant reduction in diurnal symptoms
Table III. Descriptive statistics and comparison of the pre-treatment and end of active treatment (T1-T2) changes between the treated and control group.

\begin{tabular}{|c|c|c|c|c|c|}
\hline \multirow[b]{2}{*}{$\begin{array}{l}\text { Dentoskeletal } \\
\text { measurements }\end{array}$} & \multicolumn{2}{|c|}{$\begin{array}{l}\text { Treated } \\
\text { group }\end{array}$} & \multicolumn{2}{|c|}{$\begin{array}{l}\text { Control } \\
\text { group }\end{array}$} & \multirow[t]{2}{*}{$\begin{array}{c}2 \text { Sample } \\
\text { T-test }\end{array}$} \\
\hline & Mean & SD & Mean & SD & \\
\hline \multicolumn{6}{|l|}{ Sagittal analysis } \\
\hline SNA $\left(^{\circ}\right)$ & 0,0 & 2.3 & 0.5 & 1.5 & ns \\
\hline $\operatorname{SNB}\left({ }^{\circ}\right)$ & 1.5 & 1.6 & 1.2 & 0.3 & ns \\
\hline ANB $\left(^{\circ}\right)$ & -1.5 & 2.0 & 0.2 & 1.1 & * \\
\hline Co-Me (mm) & 7.1 & 3.0 & 3.0 & 2.4 & * \\
\hline \multicolumn{6}{|l|}{ Vertical analysis } \\
\hline FMA $\left(^{\circ}\right)$ & 0.7 & 3.1 & 0.4 & 2.0 & ns \\
\hline $\mathrm{SN} \wedge \mathrm{GoGn}$ & -0.7 & 2.1 & -0.5 & 1.3 & ns \\
\hline CoGoMe $\left(^{\circ}\right)$ & 0.1 & 2.7 & -1.1 & 2.0 & ns \\
\hline \multicolumn{6}{|l|}{ Dental analysis } \\
\hline Overjet (mm) & -2.8 & 3.2 & 0.4 & 1.1 & * \\
\hline Overbite (mm) & -1.3 & 2.0 & 0.7 & 1.2 & * \\
\hline \multicolumn{6}{|l|}{ Hyoid } \\
\hline AH-C3 hor (mm) & 3.3 & 2.2 & -0.2 & 2.4 & * \\
\hline $\mathrm{AH}-\mathrm{C} 3$ vert (mm) & 1.3 & 3.3 & 1.2 & 4.1 & ns \\
\hline $\mathrm{AH}-\mathrm{FH}(\mathrm{mm})$ & 8.7 & 3.2 & 2.3 & 4.4 & * \\
\hline AH-RGn (mm) & 3.2 & 2.1 & -0.5 & 4.2 & * \\
\hline $\mathrm{AH}-\mathrm{AH} 1$ (mm) & 0.6 & 1.2 & 0.2 & 4.3 & ns \\
\hline AH-SN (mm) & 10.3 & 3.4 & 3.1 & 4.2 & * \\
\hline \multicolumn{6}{|c|}{ Soft palate and pharynx } \\
\hline U-PNS (mm) & 2.6 & 1.5 & 1.0 & 1.2 & * \\
\hline Phw1-Psp (mm) & 5.6 & 1.4 & 1.1 & 1.4 & * \\
\hline Phw2-Tb (mm) & 3.3 & 1.5 & -1.0 & 1.2 & * \\
\hline MPW (mm) & 2.6 & 1.9 & 0.5 & 1.6 & * \\
\hline PNS-AD1 & 2.8 & 1.6 & 2.0 & 1.5 & * \\
\hline PNS-AD2 & 2.5 & 1.5 & 2.3 & 1.8 & ns \\
\hline AD1-Ba & 0.1 & 1.3 & -1.1 & 1.7 & * \\
\hline $\mathrm{AD} 2 \mathrm{H}$ & -0.1 & 1.7 & -1.5 & 1.4 & * \\
\hline \multicolumn{6}{|l|}{ Tongue } \\
\hline $\mathrm{VT}(\mathrm{mm})$ & 6.8 & 2.5 & 1.1 & 2.1 & * \\
\hline H perp VT (mm) & -4.5 & 2.2 & 0.0 & 1.6 & * \\
\hline $\mathrm{VT} \wedge \mathrm{FH}\left({ }^{\circ}\right)$ & -1.4 & 1.2 & 0.7 & 1.9 & * \\
\hline
\end{tabular}

was observed in 45 of the participants who had received an oral appliance.

Thus, oral jaw positioning appliance is effective and well tolerated in the short term in children with SDB and malocclusions.

\section{Discussion}

The therapeutic effects of a mandibular advancement appliance in the treatment of obstructive sleep disorders is controversial and success rate varies substantially in 
clinical investigations ${ }^{23}{ }^{24}$. This might be due to differences in study protocols, appliance design and subject selection.

The purpose of this clinical trial was to evaluate the therapeutic effects of mandibular advancement on pharyngeal dimension in children with sleep-disordered breathing, treated with a Modified Monoblock.

Sleep-disordered breathing, during childhood, is often associated with hypertrophic tonsils, adenoids, retrognathic mandibles and transverse maxillary deficiencies. The retroposition of the mandibular complex was associated with reduced retrobasilingual space, mouth breathing, nasopharyngeal airway obstructions and relative retrodisplacement of the tongue. In our study, orthopaedic treatment in SDB patients exerted a direct beneficial effect with anterior repositioning of the tongue (V-T, $+5.7 \mathrm{~mm}$ ). The rationale for selecting the MM appliance in SDB children was to modify the occlusion and increase the intermaxillary space in which the tongue rests. Linked to this was the issue of correcting the underlying skeletal Class II pattern ${ }^{10}{ }^{11}$.

According to our study, Schütz ${ }^{25}$ observed that after mandibular advancement the anterior displacement of the mandible and hyoid bone caused an anterior traction of the tongue, which increased the posterior airway space, reduced airway resistance and facilitated nocturnal breathing. In the current study, the anterior displacement of the mandible by the functional appliances influenced the position of hyoid bone, thus improving the morphology of the upper airways ${ }^{26}$. Our results showed that the hyoid was located more anteriorly in treated patients ( $\mathrm{AH}-\mathrm{C} 3$ horizontal: $+3.6 \mathrm{~mm})$ and in a lower position $(\mathrm{AH}-\mathrm{SN},+7.2 \mathrm{~mm}$; AH-FH $+6.4 \mathrm{~mm}$ ). Schutz in 2011 evaluated the hyoid position and confirmed that the hyoid moved anteriorly but maintained its vertical position.

In our study, the treated group presented a significant decrease of $\mathrm{ANB}^{\circ}\left(-1.7^{\circ}\right)$, while mandibular length was significantly increased $(\mathrm{Co}-\mathrm{Me}:+4.0 \mathrm{~mm})$; both overjet and overbite values exhibited a significant improvement in treated subjects (OVJ: $-2.8 \mathrm{~mm}$; OVB: $-1,3 \mathrm{~mm}$ ). The absence of acrylic above the mandibular posterior teeth encouraged them to erupt. The lower molars tend to come out during the treatment time. The teeth intercuspidation stabilised and gradually improved the dental occlusion ${ }^{27}$. These results are in agreement with those reported by confirmed by Franchi ${ }^{28}$. He had observed, in fact, that the treated group presented with a significant increase in mandibular length and a decrease of both overjet and overbite, compared with controls.

Franchi et al. ${ }^{29}$ in 2006 suggested that a small pre-treatment mandibular angle $(\mathrm{Co}-\mathrm{Go}-\mathrm{Me}$ angle $<125.5)$ was correlated with the evidence of an enhanced responsiveness to functional therapy; on the basis of this observation, we analysed the Co-Go-Me angle in our results and observed that all the Class II patients in this study are "good responders", confirming that these subjects are adequate for treatment with mandibular advancement.

The therapeutic benefit from early mandibular advancement may permanently modify nasal breathing and respiration, thereby preventing obstruction of the upper airway ${ }^{18}$. It is also able to enlarge the retrolingual space and at the same time promote lingual advancement ${ }^{19}$.

Few studies have analysed the efficacy of functional appliance treatment on pharyngeal airway dimensions in growing patients with a Class II malocclusion and a retrognathic mandible. Ozbek et al. ${ }^{30}$ compared pharyngeal airway dimensions in 26 Class II children treated with the Harvold-type activator to 15 controls. They found that pharyngeal airway dimensions significantly increased after functional orthopaedic treatment. According to Ozbek $^{30}$, we observed that the dimension of upper and lower airways increased significantly in the treatment group with an increase of the length of the soft palate and of superior posterior and inferior airway space (U-PNS, $+1.7 \mathrm{~mm}$; Phw1-Psp, + $0.5 \mathrm{~mm}$; Phw2-Tb, + $0.6 \mathrm{~mm}$ ).

The middle pharyngeal width and upper and lower airway thickness showed a significant increase $(\mathrm{MPW},+2.1 \mathrm{~mm}$; PNS-AD1, $+1.2 \mathrm{~mm}$; PNS-AD2, $+1.2 \mathrm{~mm}$ ) and we also found a reduction of upper and lower adenoid thickness (AD2-H, -1.0 mm; AD1-Ba, -0.4 mm). In a study published in 2011, Restrepo et al. ${ }^{31}$ confirmed that when the measurements before and after treatment were compared, a statistically significant increase in the airway dimensions was found at the space where the adenoid tissue was located.

Orthodontic treatment based on oral appliances is considered to be a potential additional therapeutic approach for SDB in children. Orthodontists are playing an increasingly important role in managing snoring and respiratory problems by means of oral mandibular advancement devices ${ }^{19}$ and rapid maxillary expansion ${ }^{32}$.

\section{Conclusions}

Correction of mandibular retrusion by using mandibular advancement appliances in Class II malocclusion subjects with sleep disorder breathings increased the airway dimensions and improved nasal breathing. The hyoid bone was found to adopt a more anterior and lower position at the end of treatment. The dimension of upper and lower airways increased significantly in the treatment group subjects compared to the control group The tongue was found to adopt a more anterior and lower position at the end of treatment. In addition, treated patients presented a significant reduction in tongue height.

\section{References}

Carroll JL. Obstructive sleep-disordered breathing in children: new controversies, new directions. Clin Chest Med 2003;24:261-82. 
2 Nazarali N, Altalibi M, Nazarali S, et al. Mandibular advancement appliances for the treatment of paediatric obstructive sleep apnea: a systematic review. Eur J Orthod 2015;37:618-26.

3 Sinha D, Guilleminault C. Sleep disordered breathing in children. Indian J Med Res 2010;131:311-20.

4 Bianchini AP, Guedes ZC, Vieira MM. A study on the relationship between mouth breathing and facial morphological pattern. Rev Bras Otorrinolaringol 2007;73:500-5.

5 Basheer B, Hegde KS, Bhat SS, et al. Influence of mouth breathing on the dentofacial growth of children: a cephalometric study. J Int Oral Health 2014;6:50-5.

6 Grippaudo C, Paolantonio EG, Antonini G, et al. Association between oral habits, mouth breathing and malocclusion. Acta Otorhinolaryngol Ital 2016;36:386-94.

7 Pracharktam N, Hans MG, Strohl KP, et al. Upright and supine cephalometric evaluation of obstructive sleep apnea syndrome and snoring subjects. Angle Orthod 1994;64:63-73.

8 Mayer G, Meier-Ewert K. Cephalometric predictors for orthopaedic mandibular advancement in obstructive sleep apnoea. Eur J Orthod 1995;17:35-43.

9 Tangugsorn V, Skatvedt O, Krogstad O, et al. Obstructive sleep apnoea: a cephalometric study. Part II. Uvulo-glossopharyngeal morphology. Eur J Orthod 1995;17:57-67.

10 Cozza P, Ballanti F, Prete L. A modified monoblock for treatment of young children with obstructive sleep apnea. J Clin Orthod 2004;38:241-7.

11 Lione R, Buongiorno M, Franchi L, et al. Evaluation of maxillary arch dimensions and palatal morphology in mouthbreathing children by using digital dental casts. Int J Peadiatr Otorhinolaryngol 2014;78:91-5.

12 Cozza P, Polimeni A, Ballanti F. A modified monobloc for the treatment of obstructive sleep apnoea in paediatric patients. Eur J Orthod 2004;26:523-30.

13 Iwasaki T, Takemoto Y, Inada E, et al. Three-dimensional cone-beam computed tomography analysis of enlargement of the pharyngeal airway by the Herbst appliance. Am J Orthod Dentofacial Orthop 2014;146:776-85.

14 Baroni M, Ballanti F, Franchi L, et al. Craniofacial features of subjects with adenoid, tonsillar, or adenotonsillar hypertrophy. Prog Orthod 2011;12:38-44.

15 Guilleminault C, Pelayo R, Leger D, et al. Recognition of sleepdisordered breathing in children. Pediatrics 1996;98:871-82.

16 Kim YJ, Hong JS, Hwang YI, et al. Three-dimensional analysis of pharyngeal airway in preadolescent children with different anteroposterior skeletal patterns. Am J Orthod Dentofacial Orthop 2010;137:306.

17 Villa MP, Bernkopf E, Pagani J, et al. Randomized controlled study of an oral jaw-positioning appliance for the treatment of obstructive sleep apnea in children with malocclusion. Am J Respir Crit Care Med 2002;165:123-7.
18 Villa MP, Miano S, Rizzoli A. Mandibular advancement devices are an alternative and valid treatment for pediatric obstructive sleep apnea syndrome. Sleep Breath 2012;1:971-6.

19 Ballanti F, Ranieri S, Baldini A, et al. Long term therapeutic efficacy of a soft monobloc mandibular advancement device in adults with obstructive sleep apnea. Scientific World Journal 2015;2015:408469.

20 De Corso E, Bastanza G, Della Marca G, et al. Drug-induced sleep endoscopy as a selection tool for mandibular advancement therapy by oral device in patients with mild to moderate obstructive sleep apnoea. Acta Otorhinolaryngol Ital 2015;35:426-32.

21 Baccetti T, Franchi L, McNamara JA Jr. The cervical vertebral maturation (CVM) method for the assessment of optimal treatment timing in dentofacial orthopedics. Sem Orthod 2005;11:119-29.

22 Chervin RD, Hedger K, Dillon JE, et al. Pediatric sleep questionnaire (PSQ): validity and reliability of scales for sleepdisordered breathing, snoring, sleepiness and behavioral problems. Sleep Medicine 2000;1:21-32.

23 O'Sullivan RA, Hillman DR, Mateljan R, et al. Mandibular advancement splint: an appliance to treat snoring and obstructive sleep apnea. Am J Respir Crit Care Med 1995;151:194-8.

24 Rose EC, Staats R, Virchow C Jr, et al. Occlusal and skeletal effects of an oral appliance in the treatment of obstructive sleep apnea. Chest 2002;122:871-7.

25 Schütz TC, Dominguez GC, Hallinan MP, et al. Class II correction improves nocturnal breathing in adolescents. Angle Orthod 2011;81:222-8.

26 Jena AK, Singh SP, Utreja AK. Effectiveness of twin-block and Mandibular Protraction Appliance-IV in the improvement of pharyngeal airway passage dimensions in Class II malocclusion subjects with a retrognathic mandible. Angle Orthod 2013;83:728-34.

27 Clark WJ. Twin block functional therapy. applications in dentofacial orthopedics. First Edition. London: Mosby-Wolfe; 1995.

28 Franchi L, Pavoni C, Faltin K, et al. Thin-plate spline analysis of mandibular shape changes induced by functional appliances in Class II malocclusion: A long-term evaluation. $\mathrm{J}$ Orofac Orthop 2016;77:325-33.

29 Franchi L, Baccetti T. Prediction of individual mandibular changes induced by functional jaw orthopedics followed by fixed appliances in Class II patients. Angle Orthod 2006;76:950-4.

30 Ozbek MM, Memikoglu TU, Gögen H, et al. Oropharyngeal airway dimensions and functional-orthopedic treatment in skeletal Class II cases. Angle Orthod 1998;68:327-36.

31 Restrepo C, Santamaría A, Peláez S, et al. Oropharyngeal airway dimensions after treatment with functional appliances in class II retrognathic children. J Oral Rehabil 2011;38:588-94.

32 Lione R, Pavoni C, Laganà G, et al. Rapid maxillary expansion: effects on palatal area investigated by computed tomography in growing subjects. Eur J Paediatr Dent 2012;13:215-8.

Address for correspondence: Chiara Pavoni, University of Rome Tor Vergata, Department of Clinical Sciences and Translational Medicine, viale Oxford 81, 00133 Rome, Italy. Tel. +39 0620904813 E-mail: chiarapavoni@libero.it 